\title{
5. The interaction: dialogue or monologue?
}

\section{INTRODUCTION}

Having discussed the first stage in the interaction between national courts and the ECJ (the national court's question), we now turn to examine the second phase of the preliminary reference procedure from the perspective of the referring court: the ECJ's answer. This chapter assesses the views of national court judges on the procedure leading up to the answer; while the following chapter examines their appraisals of the actual answers. Together, these chapters offer fresh empirical data on an issue that we know very little about. Few studies have examined the true thoughts of national court judges on their interaction with the ECJ. ${ }^{1}$ One recent exception is the research conducted by van Gestel and de Poorter, ${ }^{2}$ who report similar findings on the basis of interviews with judges of supreme administrative courts in ten EU Member States. This chapter will corroborate those findings and will show that judges generally share most of the views expressed by scholars about the preliminary reference procedure, their interaction and the judgments of the ECJ.

This chapter starts with a brief overview of two different narratives on the interaction between the ECJ and national courts: a 'constitutional pluralist' perspective, which emphasizes heterarchical and horizontal dynamics, versus a more hierarchical depiction of the interaction (section 2). ${ }^{3}$ It subsequently presents the perspectives of national judges (section 3), while also paying attention to informal contacts beyond the formal procedure (section 4).

Cf Wallerman Ghavanini 2020c, 19; Pollack 2018.

Van Gestel and de Poorter 2017 and 2019.

Parts of this chapter focusing on Ireland and the Netherlands have already been published in Hoevenaars and Krommendijk 2021. 


\section{NARRATIVES OF MONOLOGUES AND DIALOGUES}

The literature broadly distinguishes two perspectives on the relationship between national courts and the ECJ. ${ }^{4}$ The ECJ itself refers to 'an instrument of cooperation' ${ }^{5}$ and even uses the term 'dialogue', implying that there is a shared responsibility and a large degree of equality between both sides. ${ }^{6}$ The ECJ's reliance on these cooperative elements fits within a 'constitutional pluralist' perspective which construes this interaction as cooperative, heterarchical or horizontal, because an overarching legal hierarchy is lacking. ${ }^{7}$ The highest national courts and the ECJ function on the basis of different constitutional foundations and are ultimate only in relation to their own legal system. The EU sphere is inherently more limited than the national sphere. ${ }^{8}$ This strand of literature underscores the dependency of the primacy of EU law on national constitutional law rather than the autonomous EU legal order. In addition, close cooperation is simply unavoidable, because the ECJ cannot set aside national court judgments and thus depends on national courts for compliance with its rulings. ${ }^{9}$ From this perspective, it is unsurprising that national courts at times fail to comply with the rulings of the ECJ, given that truly effective coercive enforcement mechanisms are lacking. ${ }^{10}$ The Weiss judgment of the German Federal Constitutional Court illustrates this point. ${ }^{11}$ From a normative perspective, some scholars have also argued that it is not problematic in the multi-level EU legal order that the highest (supreme or constitutional) courts claim (final) authority. ${ }^{12}$

Other EU law scholars, as well as the ECJ itself, have emphasized the relationship between the ECJ and national courts as hierarchical. ${ }^{13}$ They suggest 2013.

4 With respect to dialogue, see more broadly Slaughter 1994; Meuwese and Snel

5 Eg, Case C-182/15 Petruhhin EU:C:2016:630, para 18; Opinion 2/13 EU:C: 2014:2454, para 176. Cf 'close cooperation' in 2019/C 380/01 Recommendations to national courts and tribunals in relation to the initiation of preliminary ruling proceedings, para 2.

6 Joined Cases C-558/18 and C-563/18 Case C-619/18 Miasto Łowicz EU:C:2020: 234, para 55; Commission v Poland EU:C:2019:531, para 45; van Gestel and de Poorter $2019,142$.

Avbelj and Komárek 2012; Walker 2002; Davies and Avbelj 2018.

Arden 2014, 22.

Weiler 1991, 2403; Dyevre 2016, 109; van Gestel and de Poorter 2019, 18.

Sarmiento 2012a, 309.

Cf Burchardt 2020.

Bobíc 2017; Cartabia 2015.

Eg Timmermans 2014a. 
that the principle of the primacy of EU law leaves little room for dialogue. ${ }^{14}$ Luxembourg sits at the top of the hierarchy and has the final word, because ECJ judgments are binding. ${ }^{15}$ Procedures such as state liability (Köbler) and the infringement procedure are last-resort mechanisms that can be utilized by (legal) persons or the European Commission to prevent national courts from deviating from what Luxembourg has stipulated (see Chapter 1, section 2). ${ }^{16}$ The ECJ judgment in Commission v France illustrates that the Commission and the ECJ are increasingly willing to protect the autonomous operation of the EU legal order. For the first time, the ECJ held an EU Member State liable for the failure of its highest administrative court to refer. ${ }^{17}$ This more hierarchical perspective does not sit easily with the way in which the preliminary reference procedure is often depicted - including by the ECJ itself. It leaves little room for dialogue based on equality; and it is therefore unsurprising that scholars have instead used the term 'monologue' to refer to the interaction between national courts and the ECJ. ${ }^{18}$

The two theories or perspectives are at opposite ends of the spectrum. As this overview shows, both cooperative and hierarchical elements can be identified when examining the preliminary reference procedure. ${ }^{19}$ This raises the question as to why the ECJ has used constitutional pluralist language at all. Da la Mare and Donnelly rightly observe that the ECJ has used this language of cooperation to 'seduce' national courts into accepting its more hierarchical approach - not least because it ultimately relies on the willingness of national courts to engage with it. ${ }^{20}$

\section{THE PERSPECTIVES OF NATIONAL COURT JUDGES: A VERTICAL MONOLOGUE}

The previous section hinted at a gap between the rhetoric of dialogue and cooperation and the reality. ${ }^{21}$ The Dutch, Irish and UK judges interviewed confirmed this view and construed their relationship with the ECJ as a vertical

\footnotetext{
Fabbrini 2015; Lindeboom 2020; van Gestel and de Poorter 2019, 49.

Case C-62/14 Gauweiler EU:C:2015:400, para 16.

Case C-224/01 Köbler EU:C:2003:513.

Case C-416/17 Commission v France EU:C:2018:811, para 111.

18 Cf Claes and de Visser 2012; Pérez 2014; van Gestel and de Poorter 2019;

19 Tridimas 2015, 407.

20 De la Mare and Donnelly 2011, 377.

21 Van Gestel and de Poorter 2019, 143.
} Kochenov 2020, 17. 
one. ${ }^{22}$ Their perspectives in this regard are further corroborated by recent empirical studies. $^{23}$

National judges did not subscribe to the notion of a rather non-committal, more heterarchical discourse of cooperation with the ECJ, simply because they have a legal duty to comply with its judgments. ${ }^{24}$ Former President of the Council of State Polak considered the term 'dialogue' to be misleading, because the referring court is bound by the subsequent ECJ judgment. ${ }^{25}$ Lady Justice Arden held that the idea of mutual cooperation is in practice 'much more like an obligation of obedience' - not least because the ECJ has taken a centralizing role 'and has built up its own power', and thus stands 'at the top of a hierarchy of national courts'. ${ }^{26}$ Lord Mance also lamented that the relationship has become 'increasingly hierarchical' and does not always reflect the concepts of dialogue and mutual trust. ${ }^{27}$

National court judges were also unanimous in dismissing the suggestion that their interaction with the ECJ is a genuine dialogue of reciprocity and instead pointed to the unidirectional nature of this interaction. ${ }^{28}$ Late Council of State judge Mortelmans used the metaphor of a ferry to highlight that the two activities - the national court reference (back) and the ECJ's answer (forth) are largely separate from each other. ${ }^{29}$ A Dutch judge called the preliminary reference procedure 'a one-way Q\&A procedure that lacks timely exchange of new relevant information' ${ }^{30}$ UK judges have been most critical - both in their judgments and in extra-judicial writings and speeches - about their interaction with the ECJ. This criticism is also based on a comparison of the ECJ with the more common law-inspired ECtHR, which publishes dissenting and concurring opinions of judges and allows for amicus curiae interventions. Lord Reed claimed that it is 'a challenge' to establish a successful working relationship with the ECJ. ${ }^{31}$ Another UK judge also noted that the dialogue with Strasbourg is easier because the ECtHR is more 'outgoing' - and because

\footnotetext{
22 Loth 2017; Feteris 2017.

23 Wallerman Ghavanini 2020c; van Gestel and de Poorter 2019; Eliantonio and Favilli 2020.

24 Interviews 5, 15, 18, 27, 30, 34, 41, 72, 77, 78, 89, 91, 146, 159, 162 and 166; Clarke 2019; Evelyn Danqua v Minister for Justice and Equality [2017] IECA 20, para 36.

Polak 2015, 16.

Arden 2015; Arden 2010, 6.

Mance 2013a, paras 29 and 43.

Rosas 2007; Interviews 10, 22, 24, 31, 35, 44, 66, 81, 86, 89, 91, 208, 231 and 264.

29 Mortelmans 2011, 235.

30 De Werd 2015b, 152.

31 Reed 2014, 1.
} 
of the number of UK judges serving on the ECtHR. ${ }^{32}$ Interviewees suggested that the ECJ remains at a 'much greater distance', despite occasional meetings with its judges. ${ }^{33}$ The current UK Supreme Court also made a comparison with the ECtHR in its written response to interview questions:

Given that the status of EU law in the United Kingdom generally mandates adherence to the ECJ's rulings, there is perhaps less scope for effective dialogue with that court than with, for example, the European Court of Human Rights, the decisions of which domestic courts in the United Kingdom are required only to "take into account" pursuant to the Human Rights Act 1998. ${ }^{34}$

Both in their judgments and in interviews, judges cited several reasons for the absence of a genuine dialogue with the ECJ. The first of these concerns the attitude of the ECJ. For a true dialogue to take place, there should be a degree of equality in the positions of the interlocutors. This equality is absent from the hierarchical legal set-up of Article 267 TFEU, as well as from the subjective perceptions of judges. Some judges suggested that the ECJ at times acts pedantically like a 'know-it-all', reducing the role of the national courts to that of a mere observer. ${ }^{35}$ One Dutch judge referred to 'an ivory tower at the Kirchberg scattering its wisdom over us'; while one Irish judge claimed that the ECJ presents itself as an 'oracle'. ${ }^{36}$ Another Dutch judge pointed to the 'arrogance' of the ECJ and suggested that it treats the preliminary reference procedure like 'a high mass with the devotees at a distance'. ${ }^{37}$ A Dutch higher court judge reported that he/she had felt during a visit to Luxembourg that the attitude of the ECJ judges was: 'You come to us; we determine the rules.' ${ }^{38}$ Another Dutch highest administrative court judge noted that while the ECJ would likely insist that its cooperation with national courts is incredibly successful, national judges would not share this view. ${ }^{39}$ One judge also highlighted the defensive reaction of ECJ judges when he/she flagged up shortcomings in the ECJ case law. ${ }^{40}$ Interviewees suggested that this 'know-it-all' attitude of 'telling us what we should be doing' is also reflected

\footnotetext{
32 Interview 208.

33 Ibid.

34 Written response 15 April 2020; Amos 2012. Cf, on the German Constitutional Court and the ECtHR, Peters 2012.

35 Interviews 44, 48, 89 and 231.

36 Interviews 18 and 144.

37 Interview 16.

38 Interview 44.

39 Interview 24.

40 Interviews 12. Cf Weiler's comments on the first chapter of an edited volume written by the current ECJ President Lenaerts, in which Lenaerts easily discredited criticism of the ECJ as being based on misunderstandings, Weiler 2013.
} 
in the ECJ's judgments. ${ }^{41}$ Indeed, the 'pejorative tone' of one ECJ judgment was even explicitly mentioned in a UK High Court decision. ${ }^{42}$ An Irish judge further noted that ECJ judgments often present what appear to amount to mere magic formulas, without clarifying why the ECJ has decided in a certain way. ${ }^{43}$ A Dutch tax law judge likewise mentioned the 'apocalyptic' tone of customs decisions, in which the ECJ presents a particular tariff classification as a matter of fact: 'This is it." ${ }^{44}$ One UK judge noted that Sturgeon was rendered without hearing the parties, against the advice of AG Sharpston. According to him/her, this tarnished the reputation of the ECJ and seemed to confirm that the ECJ is 'not good at changing its mind' ${ }^{45}$ These views of Dutch, UK and Irish judges have been echoed by other commentators. For example, Weiler has criticized the ECJ's authoritarian and oracular approach, and its 'pretence of logical reasoning and inevitability of results'; while Lasser has observed that the ECJ 'boldly steps in to resolve the controversy with almost imperial confidence, speaking as if the case admits of only one correct answer ... in coldly superior terms ... and appearing self-assured' ${ }^{46}$ Interviews with judges of the supreme administrative courts in ten EU Member States further reflect these views: one German judge, for example, suggested that the ECJ has lost touch with what is happening on the ground. ${ }^{47}$

A second reason why the interaction between the ECJ and national courts falls short of a dialogue is the exclusion of national courts from the process between submission of a reference and issue of the ECJ's judgment. Some judges described this period as a 'black hole' or 'black box', and suggested that the distance between national courts and the ECJ results from the fact that the process largely takes place through written communications. ${ }^{48}$ Van Gestel and de Poorter found that judges in other Member States - including France, Germany and the Czech Republic - are also critical of this 'radio silence' and the limited supply of information throughout the process. ${ }^{49}$ It is difficult for referring courts to obtain the submissions of the (intervening) parties, which in turn makes it difficult for them to get a good overview of the case. ${ }^{50}$ One UK

\footnotetext{
41 Interview 231.

42 Newby Foods Ltd, $R$ (on the application of) v Food Standards Agency [2016] EWHC 408 (Admin), para 62.

43 Interview 144. Cf Interview 155.

44 Interview 93.

45 Interview 264. Cf Harris 2008, 376.

46 'It is so, because we say it is so. And what it means - well you will find out', Weiler 2001, 225 and 249; Lasser 2009, 107. Cf de Waele 2009, 370.

47 Van Gestel and de Poorter 2019, 135 and 138-39.

48 Interviews 5, 10, 22, 33, 35, 44, 65, 89 and 91. Cf Pollack 2017, 602.

49 Van Gestel and de Poorter 2019, 130-31.

50 Interview 35.
} 
barrister suggested that UK lawyers are 'dismayed' about the ECJ's attitude towards the solemnity of the proceedings and their near-inability to obtain copies of the pleadings of the parties. ${ }^{51}$ The UK High Court pointed out in Newby that due to these difficulties, it was unable to verify whether a certain point had been raised in the submissions to the ECJ ${ }^{52}$ One Czech judge interviewed by van Gestel and de Poorter also highlighted the unavailability of transcripts of the oral hearings in Luxembourg. ${ }^{53}$ Some judges went further and voiced feelings of exclusion. They lamented the absence of the referring court from the procedure once the reference has been made and contrasted this powerlessness with other stakeholders, whose involvement can 'take off' following a reference. ${ }^{54}$ Some Dutch judges in particular criticized this situation and noted that other parties without the necessary (case-specific) expertise have a greater say during this period than the referring court. ${ }^{55}$ The national court also cannot reply to or correct 'bullshit' submissions made by the parties, intervening Member States or the Commission. ${ }^{56}$

A third reason for the absence of a genuine dialogue is the limited transparency as to how the ECJ addresses the views of national courts. UK judges were particularly critical of this. Lord Mance vividly highlighted the problem when he argued that the ECJ:

does not in its committee style approach overtly engage with national jurisprudence (save in Advocate Generals' opinions, which are however neither binding nor decisive). That is a pity. Good fences build good neighbours, but so does good open conversation over the fences. ${ }^{57}$

The UK judges interviewed noted the contrast between the ECtHR and the ECJ, and observed that Strasbourg pays more attention and respect to what the UK Supreme Court has to say. They also pointed to the reluctance of the ECJ to engage with and refer to national courts. This was attributed to the ECJ's desire to respect the idea of equal treatment of all national courts: the expectation was that the courts in the most prominent Member States would be relied on more often, thus putting them on a higher footing than the courts in smaller jurisdictions. ${ }^{58}$ ECJ judges attributed this lack of engagement with the arguments of

\footnotetext{
$51 \quad$ Interview 243. Cf Alemanno and Stefan 2014, 124.

52 Newby Foods Ltd, $R$ (on the application of) v Food Standards Agency [2016] EWHC 408 (Admin), para 80.

53 Van Gestel and de Poorter 2019, 132.

54 Interviews 4, 54, 66 and 91.

55 Interview 66. Cf Langer 2015.

56 Interviews 5, 66 and 91; Langer 2015, 13; Wattel 2015.

57 Mance 2013b. Cf Arden 2015, para 17.

58 Interviews 231 and 264.
} 
national courts (and with the Opinions of the AG) to a desire not to be impolite and not to embarrass the referring court should it deviate from the latter's stance. $^{59}$

\section{INFORMAL CONTACTS}

One important element (or even prerequisite) for effective interaction or dialogue between the ECJ and national courts is trust. ${ }^{60}$ One Irish Supreme Court judge, for example, mentioned that the current Irish Supreme Court judges know their counterparts at the ECJ, which 'creates an atmosphere of trust' ${ }^{61}$ There have also been regular meetings between the highest national courts and the ECJ: the Irish Supreme Court, for example, visited Luxembourg in early 2018. During the visit, the PPU procedure was discussed, as well as the ECJ's practice of reformulating questions (see Chapter 6, section 2.3). ${ }^{62}$ Dutch Supreme Court judges referred to a visit to Luxembourg as a 'school trip' ${ }^{63}$ Judges of the Tax Chamber of the Dutch Supreme Court discussed the problem of ECJ judgments engaging too much with the facts of the case, as in Sonos (see Chapter 6, section 3.2) ${ }^{64}$ At the same time, Lord Reed held in 2014 that such meetings with the ECJ 'have not always been as productive'. This view is unsurprising, given that the earlier mentioned HS2 judgment was discussed between the UK Supreme Court and the ECJ in November 2014 (Chapter 4, section 2). ${ }^{65}$

Potentially even more important than these official visits are personal relationships and more informal encounters between national court and ECJ judges at conferences and other events. ${ }^{66}$ Lord Mance, for example, noted that on a personal level, relations are 'extremely good' and friendly. ${ }^{67}$ One judge interviewed also stated that UK Supreme Court judges have good personal relationships with their counterparts at the ECJ. ${ }^{68}$ Dutch Council of State judges also have informal contact with ECJ judges and the court registry. ${ }^{69}$ Several ECJ judges were previously Dutch government agents before their

\footnotetext{
59 Interviews with judges and AGs at the ECJ as reported by van Gestel and de Poorter 2019, 137. Cf de Búrca 2020.

60 De Visser 2017; Rado 2020, 84.

61 Interview 128.

62 Interviews 152, 174 and 231; Mance 2013a, para 7.

63 Interviews 33 and 37.

64 Interview 15.

65 Reed 2014, 11.

66 Interview 33.

67 Mance 2013a, para 62; Mance 2015, para 7.

68 Interview 231.

69 Interview 72.
} 
appointment to the ECJ and several court clerks spent time on secondment in Luxembourg. ${ }^{70}$ These connections and insights into ECJ procedures are considered helpful, because judges sometimes learn informally about particular steps during the period after referral. ${ }^{71}$ These informal contacts also assist judges in composing their orders for reference. One judge mentioned that he/ she had been informed by a Dutch ECJ judge that an order for reference will not be translated beyond 20 pages. $^{72}$ Lord Millett contacted an ECJ judge when he and his colleagues were unsure about the meaning of a particular ECJ judgment. ${ }^{73}$ UK Supreme Court judges have also contacted AGs from time to time when they were unsure as to whether to refer - not least where similar questions had been raised in other pending cases. ${ }^{74}$

\section{CONCLUSION}

This chapter has addressed the deficiencies in the operation of the preliminary reference procedure. It has shown that the ECJ does not approach this procedure as a (horizontal) dialogue or as a cooperative endeavour, even though it consistently employs this language. Judges in the Netherlands and the UK in particular were critical of the 'ivory tower' mentality of the ECJ, and noted that in practice, interaction with it more closely resembles a vertical monologue. Several problematic features - such as the limited involvement of national courts after the referral - were highlighted. In recent years, however, official visits and informal contacts have created a more positive dynamic and helped to build trust. This suggests that the interaction between national courts and the ECJ beyond written judgments should be carefully considered. That said, this positive impact of informal contacts has not fundamentally changed the largely critical views of national judges in relation to the quality of their interaction with the ECJ. The following chapter will discuss the judges' perspectives on the outcome of this interaction - namely, the requested ECJ rulings.

\footnotetext{
Interview 10

Interviews 10, 72 and 89.

Interview 66.

Littlepage 2014, 205.

Two judges interviewed by van Gestel and de Poorter 2019, 131.
} 